\title{
Improvement of efficiency of further vocational education under the pandemic conditions
}

\author{
Julia A. Davydova ${ }^{1 *}$, Ekaterina V. Kargapolova ${ }^{1}$, Andrey P. Koshkin ${ }^{1}$, Natalya $N$. \\ Denisenkova $^{1}$, and Valery $V$. Cherdantsev ${ }^{1}$ \\ ${ }^{1}$ Russian Economic University by G.V. Plekhanov, Department of Political Science and Sociology, \\ Moscow, Russia
}

\begin{abstract}
This work is aimed at detection of factors promoting improvement of efficient teacher-audience interaction upon distance learning. This work discusses such issues as efficiency of presentation and absorption of material in the taught disciplines, characteristics of organization conditions of audience work. The attention is paid to advantages and disadvantages of distance learning for programs of vocational retraining. This article also analyzes the necessity to upgrade engineering and methodological support of education, which agrees with the trends of progress in implementation of University 4.0 model. The research was based on sociological surveying, which provided sufficiently complete pattern of attitudes of students in vocational retraining programs to distance learning during the pandemic. On the basis of this research, it has been concluded that most students positively assessed the distance learning platforms provided by the university. At the same time, it is sufficiently difficult to concentrate attention during 1.5 hours, which forced the teacher to search for mixed forms of education, alternating practical assignments or video clips with theoretical material. It has been concluded that the distance learning is an efficient measure of protection against coronavirus, though, under usual conditions, the students prefer resident course.
\end{abstract}

Keywords: teaching, staff training, open learning system, e-learning.

\section{Introduction}

The rate of social changes in modern world requires for continuous improvement of education system and professional competences of specialists [1,2]. In the future the updating rates of technological advances will be so high that the obtained knowledge will become obsolete in 20 months [3]. A modern specialist should continuously improve his skills and habits in order to perform duties [4]. This is aided by further vocational education (FVE) [5].

In 2020 the mankind faced the COVID-19 pandemic, which designed new social reality. The policy of counteraction against COVID-19 touched all areas of society, including education [6]. The Decree of the Minister of Science and Higher Education No. 397 dated

\footnotetext{
*Corresponding author: ylkadav@mail.ru
} 
March 14, 2020 recommended universities to provide conductance of educational programs using electronic educational environment [7].

\section{Methods}

Plekhanov Russian University of Economics performs numerous programs of FVE; three of them are performed at the Chair of political sciences and sociology. Sociological studies were carried out by surveying to reveal efficiency of organization of supplemental vocational education using distance learning technologies. The studies were supported by the FVE students specializing in Multimedia journalism, Conflictology, and Social political management in digital environment $(\mathrm{N}=110)$. Two survey campaigns were carried out: April-May, 2020, and September-October, 2020.

\section{Results}

Plekhanov Russian University of Economics transited to distance learning from March 17, 2020 according to the Decree of the Minister of Science and Higher Education. The following platforms were used for learning: Webinar, ZOOM, MOODLE, and LMS.

For FVE students the main learning platform was Webinar. The advantages of this distance learning technology were comprised of high video and audio quality, direct interaction between teacher and student, opportunity to demonstrate computer screen by teacher [8]. However, not all students estimated positively this online service. Among the disadvantages, first of all, it was mentioned that this platform operated with full package of services only from desktop PC or notebook and required high speed Internet, which was not always possible during the pandemic. As for the teacher, the possibility to simultaneously connect students was restricted (3-5 persons), which complicated group work in practical classes.

The analysis of various aspects of organization of supplemental vocational education using distance learning technologies became possible on the basis of specified sociological survey of students. Thus, while responding the question "How efficient, in your opinion, is arranged the distance learning?", the average weighted estimate was 3.22 scores of 5 . Only $8 \%$ of students gave 1 score, $11 \%$ gave 5 scores.

Another set of questions referred to conditions of organization of distance learning. It was proposed to estimate the following parameters as the main criteria: availability of separate room, working place, and PC; number of persons jointly observing self-isolation regime in the territory of one household; Internet speed and its capacities for uninterrupted use of webcam.

Since the classes on supplemental education were performed in the evening, then $82 \%$ of the involved students responded that they learned when two or more persons were at home together with them, which created additional difficulties for absorption of material. The situation with availability of computers for students in the families was rather favorable: only $4.2 \%$ of total number of the surveyed persons responded that the number of computers was insufficient, which in its turn forced to determine the schedule of their usage.

A very important question referred to the quality of distance learning. The students were proposed to answer the following: "Evaluate by the scale from 1 to 5 scores the quality of material presentation by teachers". The average weighted estimate was 4.1 scores. While estimating the quality of absorption of study material upon distance learning by the scale from 1 to 5 scores, the results were significantly lower. The average weighted estimate was 2.98 scores. 
In addition, the students were asked about the most suitable platform for classes. $62 \%$ of the students responded that it was Webinar.ru, 24\% selected Zoom, the remaining students selected Discord, Skype, and Yandex Class.

Then, the students were asked an open question: "What advantages and disadvantages do they see in distance learning?" Among the advantages, the students mentioned opportunity to stay at home during the pandemic, which gave them a sense of security, not to consume excessive time for travelling but to spend it profitably instead, opportunity to create the appearance of being present when the lecture was not interesting, to perform other affairs in parallel ${ }^{\dagger}$. Among the disadvantages, the following factors were mentioned: being in a static state for a long time, computer fatigue, difficulties of attention concentration, interfering relatives, no communications with other students which raised the spirits $\$$.

One of the main tasks of this study was analysis of students' estimations of potentials of distance learning. While responding the question about readiness to continue the distance learning format, $78 \%$ of students responded negatively. Only $16 \%$ of students responded that they liked this form of learning and they preferred it to any other.

\section{Discussion}

The pandemic has promoted organization of transition of higher education to the University 4.0 model, which in its turn stimulated the university authorities to apply changes to programs of development for further implementation of distance learning technologies into conventional education [9]. However, as demonstrated by the study, the students of supplemental vocational education preferred conventional forms of learning with personal interaction with a teacher.

As mentioned by many researchers of the problem, the distance learning is as efficient as possible when the combination of synchronous and asynchronous methods is used, which allows to combine reasonably lectures and practical classes [10-12]. As a rule, most students prefer synchronous method of seminars and asynchronous method of practical classes [13].

The coronavirus pandemic has resulted in forced transition to online learning, though, the teachers and the students do not agree that this education format would become usual and would replace conventional education. Most teachers call the distance learning process profanity, arguing that it can only be efficient in an emergency situation [14]. However, as demonstrated by the survey, even the students of supplemental education are not ready to transit completely to distance learning, though, recognize certain advantages in comparison with traditional form.

\section{Conclusion}

Distance learning as an efficient tool of counteraction against the coronavirus infection in higher school requires for further comprehensive analysis. Nevertheless, it is obvious that implementation of distance technologies into education in the situation of advanced readiness and social restrictions demonstrated necessity of updating engineering and methodological support of education with consideration of all participants in the process: academic staff and students.

\footnotetext{
'In the students' version

*In the students' version
} 


\section{References}

1. C. Quesada-Pallarès, A. Sánchez-Martí, A. Ciraso-Calí, P. Pineda-Herrero, Front. Psychol. 10, 2795 (2019). https://doi.org/10.3389/fpsyg.2019.02795

2. A. Esfijani, American Journal of Distance Education, 32(1), 57-73 (2018). http://doi.org/10.1080/08923647.2018.1417658

3. R.E. Gerasimova, N.I. Gorokhova, Vestnik of North-Eastern Federal University. Pedagogy. Psychology. Philosophy, 4(16), 23-27 (2019)

4. A.A. Kritskaya, I.A. Astanina, V.I. Tychinskaya, Sinergiya Nauk, 41, 612-618 (2019)

5. G. Brunello, L. Rocco, SERIEs, 8, 315-343 (2017). https://doi.org/10.1007/s13209017-0163-z

6. S.B. Shitov, Norwegian Journal of Development of the International Science, 43(3), 62-64 (2020)

7. Prikaz Ministra nauki i vysshego obrazovaniya ot 14.03 .2020 \#397 “Ob organizatsii obrazovatel'noy deyatel'nosti v organizatsiyakh, realizuyushchikh obrazovatel'nyye programmy vysshego obrazovaniya i sootvetstvuyushchiye dopolnitel'nyye professional'nyye programmy, $\mathrm{v}$ usloviyakh preduprezhdeniya rasprostraneniya novoy koronavirusnoy infektsii na territorii Rossiyskoy Federatsii" [The Decree of the Minister of Science and Higher Education dated March 14, 2020, No. 397: On organization of educational activities in entities implementing programs of higher education and relevant additional professional programs under conditions of prevention of new coronavirus infection in the Russian Federation]

8. A. Cerqua, P. Urwin, D. Thomson, D. Bibby, Labour Economics, 67, (2020). https://doi.org/10.1016/j.labeco.2020.101907

9. Public employment services in the frontline for employees, jobseekers and employers, OECD Policy Responses to Coronavirus (COVID-19) (OECD Publishing, Paris, 2020). Accessed on: December 20, 2020. [Online]. Available: http://www.oecd.org/coronavirus/policy-responses/public-employment-services-in-thefrontline-for-employees-jobseekers-and-employers-c986ff92/

10. M. Mirzoeva, Bulletin of the Tajik National University, 10(2), 298-301 (2019)

11. O.V. Flerov, Pedagogy. Theory \& Practice, 4(2), 59-61 (2019)

12. V.L. Shatunovskiy, E.A. Shatunovskaya, Vestnik Nauki i Obrazovaniya, 9-1(87), 53$56(2020)$

13. P. Fialho, G. Quintini, M. Vandeweyer, Returns to different forms of job related training: Factoring in informal learning, OECD Social, Employment and Migration Working Papers, 231 (OECD Publishing, Paris, 2019). https://dx.doi.org/10.1787/b21807e9-en

14. S.G. Dekhal, Voprosy Pedagogiki, 6(2), 34-38 (2019) 